\title{
Influence Of Acacia nilotica On Arsenic Induced Genotoxicity In Male and Female Mice
}

\author{
INAS S. Ghaly AND ZEINAB E. HANAFY* \\ National Research Centre, Cell Biology Department And \\ Department of Zoology, Faculty of Science (Girls), Al-Azhar University*
}

\begin{abstract}
For centuries, plants have been used in traditional medicine and there has been recent interest in the chemopreventive properties of compounds derived from plants. In the present study, we investigated the effects of extracts of Acacia nilotica leaves on the genotoxicity of arsinic .

Arsenic contamination in groundwater a global human health hazard .There is no effective remedial action of chronic arsenicsis. However, a well-nourished diet can modulate the onset of adverse health effects and delayed the effect of arsenic in drinking water. In the present work, genotoxic effects were induced by sodium arsenate through oral administration, and the protective effect of Acacia nilotica was studied. Chromosomal aberrations were more pronounced in sodium arsenate treated mice, while supplementation of Acacia nilotica with sodium arsenate reduced the incidence of the aberrations. The mean of DNA fragmentation induced by sodium arsenate was highly significant increase. However, the administration of Acacia nilotica significantly decreased DNA fragmentation induced by sodium arsenate.

The mean number of sperms, were decreased significantly after treatment with sodium arsenate, while administration of Acacia nilotica increased the number of sperm in mice treated with sodium arsenate, and also decreased the percentage of sperm abnormalities induced by sodium arsenate.
\end{abstract}

The outcome of study showed that Acacia nilotica has the efficiency to encounter the genotoxic effects induced by arsenic.

\section{Introduction:}

For centuries, arsenic has played an important role in science and medicine. Arsenic for its environmental perversiveness has gained unexpected entrance to the human body through food, water and air, thereby poising a great threat to public health due to its toxic effect and carcinogenicity. Thus, in modern scenario arsenic is synonymous with "toxic" and is documented as a paradoxical human carcinogen, although its mechanism of induction of neoplasia remains elusive (Mahata et al., 2004).

Arsenic has been found to be genotoxic. It induced sister chromatid exchanges and is clastogenic in a range of in vitro systems using both human and animal derived cells ( Bernstam\&Nriagu
2000 and Gradecka et al., 2001). Other studies have found that exposure to inorganic arsenic increases the frequency of micronuclei, chromosome aberrations and sister chromatid exchanges both in humans and experimental animals. (Mahata $\boldsymbol{e t}$ al., 2003; Mahata et al., 2004 and Avani\&Rao 2007 ). De Chaudhuri et al., (2008) showed that health effects (i.e. peripheral neuropathy, conjunctivitis and respiratory illness) and chromosomal aberrations were significantly higher in the keratotic group compared to individuals with no skin lesions.

Arsenic has also been shown to enhance the clastogenicity and mutagenicity of other DNA damaging agents. Other change in vitro, are related 
directly, or indirectly to cell replication (Simeonova and Luster 2000). Gradecka et al., (2001) suggested that arsenic acts through a series of chemical reactions in the cell, interacting strongly with nearby molecules, and changing the structure of cellular components such as DNA. Arsenic has been shown not to affect DNA directly, but to intensify the toxic effects of other physical and chemical agents by inhibiting DNA repair, changing cell redox potential, and altering DNA methylation of cell-cycle control proteins.

Celino et al., (2009) suggested that low doses of arsenic may inhibit spermatogenesis via steroidogenesis suppression, while high doses of arsenic induce oxidative stress-mediated germ cell apoptosis.

Plants are important source of potentially useful structures for the development of new chemotherapeutic agents. The first step towards this goal is the in vitro antibacterial activity assay (Tona et al., 1998). Many reports are available on the antiviral, antibacterial, antifungal, antihelminthic, antimolluscal and anti-inflammatory properties of plants (Samy \& Ignacimuthu, 2000; Palombo \& Semple, 2001; Kumaraswamy et al., 2002; Stepanovic et al., 2003;Bylka et al., 2004; Behera \& Misra, 2005; Govindarajan et al., 2006 and Mahesh \&Satish 2008). Some of these observations have helped in identifying the active principle responsible for such activities and in the developing drugs for the therapeutic use in human beings.

Acacia nilotica belonging to the Leguminosae family and sub-family Mimosaceae has been subjected to long term clinical trials in folk medicine (EITahir etal.,1999). The bark, root, gum, leaves and flowers have found use for skin diseases, diarrhoea, dysentery, cough, diabetes, eczema, wound healing, burning sensation and as an astringent, demulcent, anti-asthmatic. It has been reported that various parts of the plant are rich in tannins (ellagic acid, gallic acid, tannic acid), stearic acid, vitamin-C (ascorbic acid), carotene, crude protein, crude fiber, arabin, calcium, magnesium and selenium (Marohasy, 1995; Mohanty et al., 1996 and Sotohy et al., 1997).

Acacia nilotica extracts were found in the Ames assay to have potent antimutagenic effects against the direct acting mutagens NPD, sodium azide, and the S9-dependent mutagen 2-AF (Arora et al., 2005). Hédi et al., (2007) indicate that extracts of Acacia salicina leaves are a significant source of compounds with antigenotoxic and antioxidant activity (most likely phenolic compounds and sterols), and thus may be useful for chemoprevention.

In this study, we evaluated the genotoxic effects of arsenic in male and female mice and the possible protective effect of Acacia nilotica on genotoxic induced by sodium arsenate.

\section{Material and Methods:}

\section{Material}

Sodium arsenate (Sigma Chemical, USA)

Acacia nilotica extracts

\section{Preparation of Acacia nilotica extracts}

Acacia nilotica leaves were collected from Upper Egypt. Leaves were air-dried in shade without direct exposure to sun rays and powdered. Leaves were distilled in a round bottom flask using double distilled water (DDW) at $60^{\circ} \mathrm{C}$. The procedure was repeated thrice for $12 \mathrm{hrs}$ duration and the leftover residue after the third distillation was filtered and the remaining distilled water was allowed to evaporate. Thereafter, remaining material was dried in oven and collected (Meena et al., 2006).

\section{Animals and Experimental Design:}

Forty male and forty female Swiss albino mice (body weight 20-25g) were obtained from the house of experimental animals, the National Research Center, Cairo, Egypt. The animals were kept under the normal healthy laboratory condition and divided into four groups to carry out the experimental study. These groups were as follows: 
1- Control group.

2- Acacia nilotica (AN) group, received oral daily $30 \mathrm{mg} / \mathrm{kg}$ body weight Acacia nilotica.

3- Arsenic group, received oral sodium arsenate at a dose of $5.0 \mathrm{mg} / \mathrm{kg}$ body weight.

4- Acacia nilotica and sodium arsenate group, received Acacia nilotica at a dose of $30 \mathrm{mg} / \mathrm{kg}$ body weight and received sodium arsenate at a dose of $5.0 \mathrm{mg} / \mathrm{kg}$ body weight.

Acacia nilotica and sodium arsenate were ingested through a gastric tube. The dose was given daily for 6 weeks.

After 6 weeks of drug administration, the animals were sacrificed and bone marrow was collected. Chromosome preparation from bone marrow cells of both male and female mice was prepared according to the procedure of Yosida and Amano (1965).

DNA fragmentation in liver cells was carried out according to Burton (1956) and Perandones et al., (1993)

Sperm abnormality preparation from tests cells was prepared according to the method of Wyrobek and Bruce (1975).

\section{Statistical analysis:}

All data were statistically analyzed using the general linear models procedure of the statistical analysis system (SAS Institute, 1982). The significance of the differences among treatment groups was determined by Waller-Duncan ratio (Waller and Duncan, 1969). All statements of significance were based on probability of $\boldsymbol{P} \leq 0.05$.

\section{Results}

\section{Chromosome aberration}

\section{In male}

In bone marrow cells of mice (control group), the means of aberrant cells were 4.0. The frequency of aberrant cells in the group of animal treated with Acacia nilotica only slightly increased when compared to control 5.9. The chromosomal abnormalities showed an increase in the structure types: gap 1.6, centric fusion 0.5 and end to end association 2.0. However, deletion and break type was the same means, i.e. $1.0 \& 0.8$ (table 1 ).

The group of animal treated with sodium arsenate showed a significant increase in the frequency of abnormal cells (11. 2). The group of animal treated with Acacia nilotica and sodium arsenate, has shown a significant decrease in the number of cell carrying aberrations at a means of 8.7.All types of chromosome aberration exhibited a decrease in number. The number in gaps, deletion, break, centric fusion and end to end association types were $2.0,2.2,0.9,0.4 \& 2.8$ (table1).

\section{In female}

In mice treated with sodium arsenate, the frequency of chromosome aberration before treatment was 5.4 (control) and after treatment was a high significant increase (11.8). All types of chromosome aberration exhibited increase in number. The number in gaps, deletion, break, centric fusion and end to end association types were 2.8, 3.6, 2.4, $0.4 \& 1.8$ (table 2).

The effect of Acacia nilotica on the frequency of abnormal cells caused increase in the frequency chromosome aberration. It was observed at a level of 6.5. The change in chromosome aberrations showed gaps, deletion, break and end to end association (table 2).

Treatment with Acacia nilotica is effective against all types of chromosome aberrations appeared in mice treated with sodium arsenate. There is a significant reduction in the percentage of aberrant cells as well as chromosome aberrations in the treated group compared with arsenic group. The number in gaps, deletion, break and end to end association types were 1.8, 2.3, $1.4 \& 0.5$ (table 2). 


\section{DNA fragmentation}

\section{In male}

The mean of DNA fragmentation showed nonsignificant increase after treatment with Acacia nilotica compared to control group. However the mean of DNA fragmentation induced by sodium arsenate highly significant increased. Administration of Acacia nilotica decreased DNA fragmentation induced by sodium arsenate (table 3).

\section{In female}

Nonsignificant increased was shown when mice treated with Acacia nilotica. The mean of DNA fragmentation induced by sodium arsenate highly significant increased. However, the administration of Acacia nilotica significantly decreased DNA fragmentation induced by sodium arsenate (table 4).

\section{Sperm count in male mice}

Treatment with Acacia nilotica only is effective on the number of sperm in mice at mean of 18.67. However, the mean number of sperm induced by sodium arsenate highly significant decreased (10.24). Administration of Acacia nilotica increased the number of sperm in mice treated with sodium arsenate (15.79) (table 5).

\section{Sperm abnormality}

Sodium arsenate induced an increase in the means of abnormal sperm. Such means was found to be highly significant compared with control group. Table (6) illustrates the means of the different types of sperm abnormalities after treatment with arsenic. The dominant abnormalities found were amorph, without hook, banana, big head and coiled tail. The other abnormalities were few in number.

Acacia nilotica highly significant decreased the percentage of sperm abnormalities induced by sodium arsenate. All types of sperm abnormalities exhibited a decrease in number (table 6).

The group of animal treated with Acacia nilotica only has shown a significant increase in the means of sperm abnormalities at a means of 38.2 (table 6) 
Table 1: Total chromosomal aberration in bone marrow cells of male mice treated with Acacia nilotica extract and arsenic $($ Mean \pm S.D)

\begin{tabular}{|c|c|c|c|c|c|c|c|c|}
\hline \multirow[b]{2}{*}{ 气̆ } & \multicolumn{5}{|c|}{ Structural chromosomal aberrations } & \multirow[b]{2}{*}{$\begin{array}{c}\text { More } \\
\text { aberrations } \\
\text { in one cell }\end{array}$} & \multicolumn{2}{|c|}{ Total chromosomal aberrations } \\
\hline & Gap & Deletion & $\begin{array}{l}\text { Break and } \\
\text { fragment }\end{array}$ & $\begin{array}{l}\text { Centric } \\
\text { fusion }\end{array}$ & $\begin{array}{l}\text { End to End } \\
\text { association }\end{array}$ & & $\begin{array}{l}\text { including } \\
\text { gap }\end{array}$ & excluding gap \\
\hline Control & $1.2 \pm 0.83$ & $1.0 \pm 0.7$ & $0.8 \pm 0.44$ & $0.4 \pm 0.2$ & $0.6 \pm 0.54$ & $0.4 \pm 0.2$ & $4.0 \pm 0.7$ & $2.8 \pm 0.7$ \\
\hline Acacia nilotica & $1.6 \pm 0.54$ & $1.0 \pm 0.0$ & $0.8 \pm 0.6$ & $0.5 \pm 0.4$ & $2.0 \pm 0.7 *$ & 0.0 & $5.9 \pm 0.89 *$ & $4.3 \pm 0.71$ \\
\hline Arsenic & $2.6 \pm 0.5^{*}$ & $2.4 \pm 0.89 *$ & $1.4 \pm 0.54$ & $0.6 \pm 0.54$ & $3.2 \pm 1.09 * *$ & $1.0 \pm 0.7 *$ & $11.2 \pm 0.83 * *$ & 8. $6 \pm 1.1 * *$ \\
\hline $\begin{array}{c}\text { Arsenic + } \\
\text { Acacia nilotica }\end{array}$ & $2.0 \pm 0.7 *$ & $2.2 \pm 0.44 *$ & $0.9 \pm 0.2$ & $0.4 \pm 0.2$ & $2.8 \pm 0.5^{* *}$ & $0.4 \pm 0.2$ & $8.7 \pm 0.54 * *$ & $6.7 \pm 0.54 *$ \\
\hline
\end{tabular}

\footnotetext{
$*$ Significant $\quad * *$ highly significant $\quad(\mathrm{P}<0.05)$
} 
Table 2: Total chromosomal aberration in bone marrow cells of female mice treated with Acacia nilotica extract and arsenic (Mean \pm S.D)

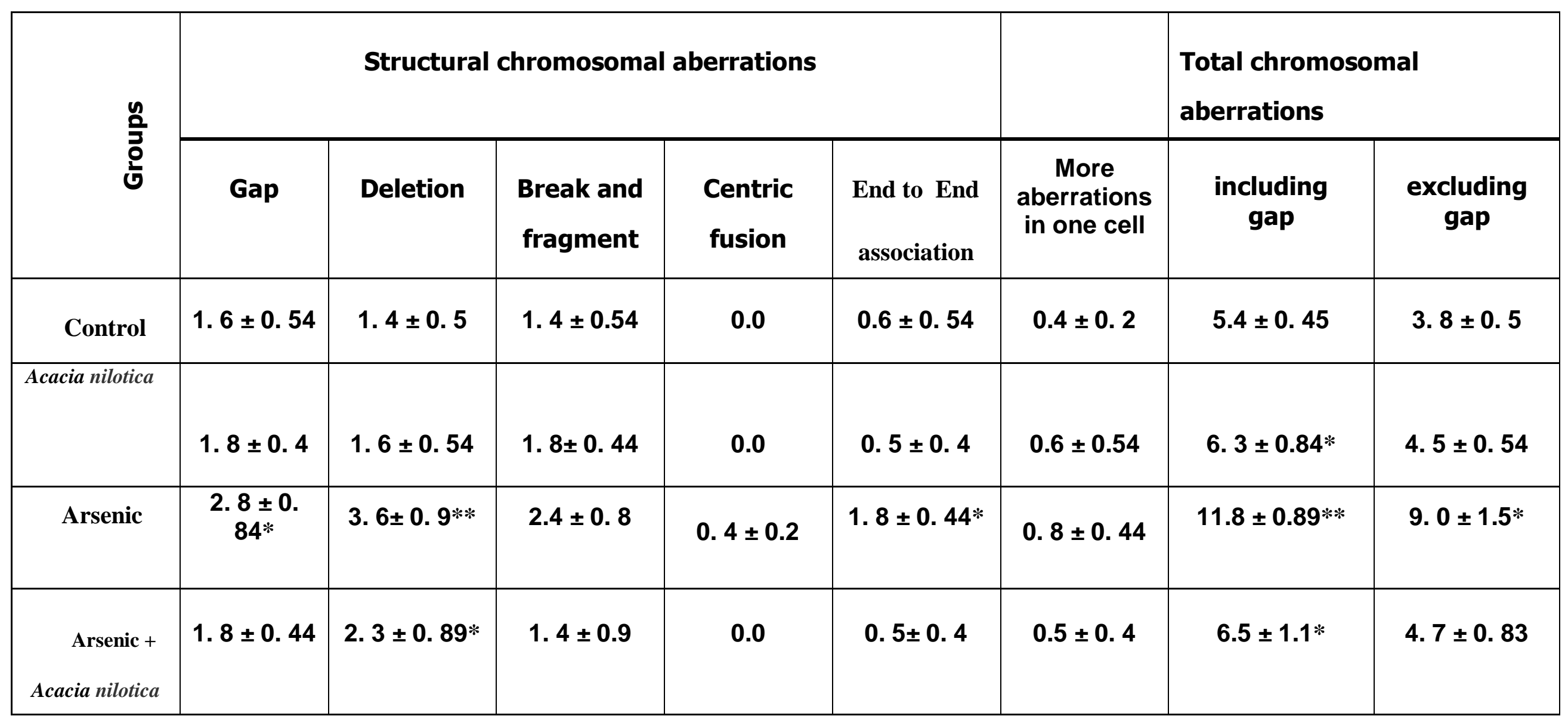

* Significant $\quad * *$ highly significant $\quad(\mathrm{P}<0.05)$ 
Table (3): The effect of arsenic and Acacia nilotica extract on DNA fragmentation in male mice

\begin{tabular}{|cc|}
\hline Groups & $\begin{array}{c}\text { DNA fragmentation } \\
\text { for male } \\
\text { Mean } \pm \text { S.E }\end{array}$ \\
\hline Control & $13.98 \pm 0.8$ \\
\hline Acacia nilotica & $16.93 \pm 0.81$ \\
\hline Arsenic & $26.26 \pm 0.75^{*}$ \\
\hline $\begin{array}{c}\text { Arsenic }+ \text { Acacia } \\
\text { nilotica }\end{array}$ & $18.05 \pm 0.95$ \\
\hline
\end{tabular}

* Significant $\quad(\mathrm{P}<0.05)$

Table (4): The effect of arsenic and Acacia nilotica extract on DNA fragmentation in femal mice

\begin{tabular}{|cc|}
\hline Groups & $\begin{array}{c}\text { DNA fragmentation } \\
\text { for female } \\
\text { Mean } \pm \text { S.E }\end{array}$ \\
\hline Control & $18.27 \pm 0.58$ \\
\hline Acacia nilotica & $23.68 \pm 0.87$ \\
\hline Arsenic & $29.86 \pm 0.14 *$ \\
\hline $\begin{array}{c}\text { Arsenic }+ \text { Acacia } \\
\text { nilotica }\end{array}$ & $24.06 \pm 1.1 *$ \\
\hline
\end{tabular}

* Significant $\quad(\mathrm{P}<0.05)$

Table (5): The effect of arsenic and Acacia nilotica extract on epididymal count in male mice

\begin{tabular}{|l|c|c|c|}
\hline \multicolumn{1}{|c|}{ Groups } & $\begin{array}{c}\text { No.of } \\
\text { animals }\end{array}$ & Sperm count (million/ml) & $(\%)$ of abnormal cells \\
\hline Control & 5 & $24.0218 \pm 1.4794$ & 5.06 \\
\hline Acacia nilotica & 5 & $18.6707 \pm 0.9793 *$ & 7.2 \\
\hline Arsenic & 5 & $10.2390 \pm 0.7239 * *$ & 13.05 \\
\hline $\begin{array}{c}\text { Arsenic }+ \\
\text { Acacia nilotica }\end{array}$ & 5 & $15.7860 \pm 1.0649 *$ & 11.1 \\
\hline
\end{tabular}

* Significant $\quad * *$ highly significant $\quad(\mathrm{P}<0.05)$ 
Table (6): Total sperm abnormality of male mice treated with Acacia nilotica extract and arsenic (Mean \pm S.D)

\begin{tabular}{|c|c|c|c|c|c|c|c|}
\hline \multirow{2}{*}{ Groups } & \multicolumn{4}{|c|}{ head abnormalities } & \multicolumn{2}{|c|}{ Tail abnormal } & \multirow{2}{*}{$\begin{array}{c}\text { Total abnormal } \\
\text { sperm }\end{array}$} \\
\hline & amorphous & Without hook & banana & big & divided & coiled & \\
\hline control & $12.4 \pm 0.54$ & $4.0 \pm 1.2$ & $0.4 \pm 0.2$ & 0.0 & $0.6 \pm 0.5$ & $8.2 \pm 1.0$ & $25.6 \pm 1.3$ \\
\hline Acacia nilotica & $17.8 \pm 1.3^{*}$ & $7.8 \pm 1.4^{*}$ & $1.8 \pm 0.8 *$ & $1.4 \pm 0.5^{*}$ & $0.4 \pm 0.2$ & $9.0 \pm 1.0$ & $38.2 \pm 1.2^{*}$ \\
\hline Arsenic & $27.2 \pm 1.4 * *$ & $15.0 \pm 1.5^{* * *}$ & $3.2 \pm 1.3 * *$ & $2.0 \pm 1.0^{*}$ & $0.6 \pm 0.54$ & $27.4 \pm 1.1 *$ & $75.4 \pm 0.9 * *$ \\
\hline $\begin{array}{c}\text { Arsenic }+ \\
\text { Acacia nilotica }\end{array}$ & $25.0 \pm 1.2^{* *}$ & $5.2 \pm 1.0$ & $1.2 \pm 1.0 *$ & $1.2 \pm 0.8^{*}$ & $0.9 \pm 0.6$ & $26.26 \pm 0.82 *$ & $59.7 \pm 1.5^{* *}$ \\
\hline
\end{tabular}

* Significant $\quad * *$ highly significant $\quad(\mathrm{P}<0.05)$ 


\section{Discussion}

Human activities have increased the possibility of exposure to naturally occurring metals causing a greater risk of exposure to toxic levels. The exposure of metals such as arsenic constitutes a major health concern. Arsenite induces DNA damage referred to as genotoxicity in human cells within a pathologically meaningful dose range. Arsenic toxicity is cell specific. Therefore, it is important that target cells be used for investigations (Hamadeh et al., 2002).

The genotoxicity of arsenic is due largely to the trivalent arsenicals. In human, arsenic is a chromosomal mutagen. Arsenic appears to have limited ability to induce point mutations. Elevated frequencies of micronuclei, chromosomal aberrations and aneuploidy were detected in the peripheral lymphocytes or urothelial cells, or both, of people exposed to elevated levels of arsenic. In mammal cells, arsenic caused various types of chromosomal mutations and aneuploidy (IARC, 2004).

The results of the present study showed that sodium arsenate is a genotoxic agent. This was evidenced by the increase incidence of chromosomal aberrations particularly the gap type in animals receiving arsenic. The importance of recording gaps in assessing the genotoxic effects of compound is controversial. Some authors considered gaps to be a sensitive indicator of chemically induced chromosomal damage, while others considered the scoring of gaps to be highly subjective and, therefore, an unsuitable indicator of genotoxicity (Hassan, 1997).

In the present study, sodium arsenate showed a significant increase in the frequency of abnormal cells. Also all types of chromosome aberration exhibited an increase in number. There are several reports on inorganic arsenic increases the frequency of micronuclei, chromosome aberrations and sister chromatid exchanges (Gebel, 2001and Waclavicek et al., 2001). Mahata et al. (2003) indicates that enhanced rates of chromosomal aberrations
(CA) and sister chromatid exchanges (SCE) among the residents of North 24 Pargons are indicative of the cytogenetic damage due to long term exposure to arsenic through consumption of contaminated water.Mahata et al. (2004) show that sodium arsenite induced a significantly higher percentage of aberrant cells in the lymphocytes of control individuals than in the lymphocytes of both the exposed groups. De Chaudhuri et al. (2008) suggests that individuals with keratosis are more susceptible to arsenic-induced health effects and genetic damage and that the arginine variant of p53 can further influence the repair capacity of arsenicexposed individuals, leading to increased accumulation of chromosomal aberrations. Singh et al. (2008) indicate that chromosomal aberrations were more pronounced in arsenic treated mice.

The mean of DNA fragmentation induced by sodium arsenate highly significant increased. However, the administration of Acacia nilotica significantly decreased DNA fragmentation induced by sodium arsenate. Arsenic has been shown to induce DNA damage in human cells. Inorganic arsenic inhibits DNA repair. Specifically, a significant increase in comet tail-length at doses 0 to $6.45 \mathrm{mg} / \mathrm{kg}$ body weight demonstrated that arsenic trioxide cause DNA damage effectively (Gebel, 2001 and Waclavicek et al., 2001). Arsenic was highly genotoxic to the three cell lines. No significant differences in DNA cleavage were observed between acute and chronic exposures. In acute exposure, arsenic genotoxicity was more severe with dendritic cells, while melanocytes were more sensitive to arsenic cytotoxicity. Similarly, chronically exposed dendritic cells showed the maximum genotoxic damage while melanocytes were more sensitive to arsenic cytotoxicity (Evans $\boldsymbol{e t}$ al., 2004). Chronic arsenic exposure caused significant single-strand DNA damage in lymphocytes as depicted by comet with a tail in arsenic-exposed cells compared with the control cells. Mishra and Flora (2008) suggested that arsenic induces differential oxidative stress in brain regions with cortex 
followed by hippocampus and causes single-strand DNA damage in lymphocytes. Functional profiling using homozygous deletion mutants provided evidence of the requirement of highly conserved biological processes in the response against both arsenicals including tubulin folding, DNA double-strand break repair, and chromatin modification (Jo et al., 2009).

One of the possible mechanisms suggesting arsenic toxicity is the generation of reactive oxygen species (ROS).Liu et al. (2001) found that reactive oxygen species, particularly hydroxyl radicals, play an important causal role in the genotoxicity of arsenical compounds in mammalian cells.

The present study indicated that sodium arsenate reduced the number of sperm in mice. Also, sodium arsenate induces an increase the percentage of abnormal sperm and an increase in the different types of sperm abnormalities was observed after treatment with sodium arsenate. Celino et al. (2009) suggested that low doses of arsenic may inhibit spermatogenesis via steroidogenesis suppression, while high doses of arsenic induce oxidative stress-mediated germ cell apoptosis. Acacia nilotica increased the number of sperm in mice treated with sodium arsenate and highly significant decreased the percentage of sperm abnormalities induced by sodium arsenate. All types of sperm abnormalities exhibited a decrease in number.

In the present study, Acacia nilotica was effective against all types of chromosome aberrations appeared in mice treated with sodium arsenate. There was a significant reduction in the percentage of aberrant cells as well as chromosome aberrations in the treated group compared with arsenic group. Meena et al. (2006) found that a significant reduction in the frequency of micronuclei was observed in mice treated by oral gavage with the aqueous extracts of Acacia nilotica. There is also a significant decrease in total chromosomal aberrations in the form of chromatid breaks, chromosome breaks, centric rings, dicentrics, acentric fragments and exchange as compared with the group given 7, 12-dimethylbenz (a)anthracene (DMBA).

Acacia nilotica significantly decreased DNA fragmentation induced by sodium arsenate. Antimutagens and anticarcinogens are natural or synthetic substances able to inhibit or to reduce spontaneous or induced DNA alteration. They react directly with mutagens or on the process of their activation (El Hamss and Idaomar, 2002).

Acacia nilotica showed a marked antimutagent effect. Furthermore, it was more effective against indirect acting mutagens (Arora etal., 2003).

Acacia nilotica (Linn.) gum, flower and leaf extract may play an additional and synergistic antimutagenic role in the presence of tannins (ellagic acid, gallic acid and tannic acid), crude protein, crude fiber, arabin, calcium, magnesium, selenium, stearic acid with three phenoilic components (viz. Kaempferol-3-glucoside, isoquercetin, leucocyanidin) Vit.C (ascorbic acid), carotene, alkaloids and saponins (Sotohy et al., 1997 and Arora etal., 2003).

Chang et al. (2001) indicate that both bark and heartwood extracts of Acacia confusa clearly have strong antioxidant effects. Furthermore, the heartwood extract protected PhiX174 supercoiled DNA against strand scission induced by ultraviolet photolysis of $\mathrm{H} 2 \mathrm{O} 2$, , and it reduced the amounts of intracellular hydrogen peroxide, a reactive oxygen species, when it was co-incubated with human promyelocytic leukemia (HL-60) cells under oxidative stress. Bouhlel et al. (2008) showed that Acacia salicina extracts decreased the DNA damage caused by $\mathrm{H}_{2} \mathrm{O}_{2}$.

In conclusion, arsenic was highly genotoxic in both male and female mice, while Acacia nilotica reduced the percentage of aberrant cells, decreased DNA fragmentation, increased the number of sperm and decreased the percentage of sperm abnormalities. Acacia nilotica protected the cells from the oxidative stress induced by arsenic. 


\section{References:}

Arora, S.; Brits, E.; Kaur, S.; Kaur, K.; Sohi, R. S.; Kumar S. and Verschaeve, L. (2005): Evaluation of Genotoxicity of Medicinal Plant Extracts by the Comet and VITOTOX $^{\circledR} \quad$ Tests. $\quad$ J.Env.Path.Tox.Oncol. 24:193-200.

Arora, S.; Kaur, K. and Kaur, S. (2003): Indian medicinal plants as a reservoir of protective phytochemicals. Teratog Carcinog Mutagen, 23: 295-300.

Avani, G. and Rao,M.V. (2007):Genotoxic effects in human lymphocytes exposed to arsenic and vitamin A. Toxicology in Vitro, 21:626-631.

Behera, S.K. and Misra, M.K. (2005): Indigenous phytotherapy for genito-urinary diseases used by the Kandha tribe of Orissa, India. J. Ethnopharmacol., 102: 319-325.

Bernstam,L. and Nriagu,J. (2000) : Molecular aspects of arsenic stress. J.Toxicology and Environmental Health, 3:293322.

Bouhlel,I.;Kilani,S.;Skandrani,I.;Amar,R.B.; Nefatti,A.; Laporte,F.; Hininger-Favier,I.; Ghedira,K.and Chekir-Ghedira, L. ( 2008) : Acacia salicina extracts protect against DNA damage and mutagenesis in bacteria and human lymphoblast cell K562 cultures .Nutrition Research, 28: 190-197.

Burton, K. (1956): A study of the condition and mechanisms of the diphenylamine reaction for the estimation of deoxyribonucleic acid. Biochem.J. 62: 315-323.

Bylka, W.; Szaufer-Hajdrych,M.; Matalawskan, I. and Goslinka, O. (2004):

Antimicrobial activity of isocytisoside and extracts of Aquilegia vulgaris L. Lett.

Appl. Microbiol., 39: 93-97.

Celino, F.T.; Yamaguchi, S.; Miura, C. and Miura, T. (2009): Arsenic inhibits in vitro spermatogenesis and induces germ cell apoptosis in Japanese eel (Anguilla japonica). Reproduction, 138: 279-287.

Chang ,S.T.; Wu ,J.H.; Wang , S.Y.; Kang, P.L.; Yang, N.S. and Shyur, L.F.

2001): Antioxidant activity of extracts from Acacia confusa bark and heartwood. J Agric Food Chem., 49(7):3420-3424.

De Chaudhuri, S.; Kundu, M.; Banerjee, M.; Das, J.K.; Majumdar, P.; Basu, S., Roychoudhury, S.; Singh, K.K.and Giri,A.K. (2008): Arsenic-induced health effects and genetic damage in keratotic individuals: involvement of p53 arginine variant and chromosomal aberrations in arsenic susceptibility. Mutat Res., 659(1-2):118-125.

El Hamss, R. and Idaomar, M. (2002): Antimutagens and anticarcinogenic agents, identifiction and mechanism of action of food xenobiotics. Therapie, 57: 512-517.

EI-Tahir, A.;Satti, G.M. and Khalid, S.A. (1999). Antiplasmodial activity of selected sudanese medicinal plants with emphasis on Acacia nilotica. Phytother Res, 13, 474-478.

Evans, B. G.; Cohly ,H. H. P.; Hongtao, Yu .and Tchounwou,P. B. ( 2004):

Arsenic-Induced Genotoxic and Cytotoxic Effects in Human Keratinocytes, Melanocytes and Dendritic Cells.. Int. J. Environ. Res. Public Health, 1(2): 83-89.

Gebel, T. W. (2001): Genotoxicity of arsenical compounds. Int $\mathrm{J}$ Hyg Environ

Health, 203(3): 249- 262.

Govindarajan, R.; Vijayakumar, M. ; Singh, M. ; Rao, C.H.V.; Shirwaikar,

A.; Rawat, A.K.S. and Pushpangadan, P. ( 2006). Antiulcer and antimicrobial

activity of Anogeissus latifolia. J. Ethnopharmacol., 106: 57-61.

Gradecka, D.; Palus, J. and Wasowicz, W. (2001): Selected mechanisms of genotoxic effects of inorganic arsenic compounds. Int. J. Occup. Med. Environ. Health, 14(4): 317-328.

Hamadeh, H. K.; Trouba, K. J.; Amin, R. P.; Afshari C. A. and Germolec, D. (2002): Coordination of altered DNA repair and damage pathways in arsenite-exposed keratinocytes. Toxicol Sci, 69(2): 306- 316.

Hassan, N.H. (1997): Miconazole genotoxicity in mice .J.Appl.Toxicol.,17:313-319.

Hédi, B. M.; Jihed B.; Inks, B.; Amor, M.; Stephane, B.; Jemni B. C.; Kamel, G. and Leila C. (2007): Antigenotoxic activities of crude extracts from acacia salicina leaves. Environmental and molecular mutagenesis, 48:58-66.

IARC (International Agency for Research on Cancer) (2004): Arsenic in drinking water (Group 1), Vol.84: p.39.

Jo, W. J.; Loguinov, A. ; Wintz, H.; Chang, M.; Smith, A.H.; Kalman, D.; Zhang, L.; Smith, M.T. and Vulpe, C. D. (2009): Comparative Functional Genomic Analysis Identifies Distinct and Overlapping Sets of Genes Required for Resistance to Monomethylarsonous Acid (MMA ${ }^{\mathrm{III}}$ ) and Arsenite $\left(\mathrm{As}^{\mathrm{III}}\right)$ in Yeast. Toxicological Sciences, 111(2):424-436.

Kumaraswamy, Y.; Cox, P.J.; Jaspars, M. ; Nahar, L. and Sarker, S.D. (2002): Screening seeds of Scottish plants for antibacterial activity. J. Ethnopharmacol., 83:73-77.

Liu, S.X.; Athar, M.; Lippa, I.; Waldren, C.A. and Hei, T.K. (2001): Induction of oxyradicals by arsenic : implications for mechanisms of genotoxicity. Proceeding National Academy Science(U.S.A.),98:16431648 . 
Mahata, J.; Basu, A.; Ghoshal, S.;Sarkar, J.N.; Roy ,A.K.;Poddar, G.; Nandy, A.K .; Banerjee, A.; Ray, K.; Natarajan, A.T.; Nilsson, R.and Giri, A.K.. (2003): Chromosomal aberrations and sister chromatid exchanges in individuals exposed to arsenic through drinking water in West Bengal, India. Mutat Res., 10: 534(1-2):133-143.

Mahata, J.; Chaki, M.; Ghosh, P.; Das, L.K.; Baidya, K.; Ray, K.; Natarajan, A.T.andGiri, A.K .(2004): Chromosomal aberrations in arsenic-exposed human populations: a review with special reference to a comprehensive study in West Bengal, India. Cytogenet Genome Res., 104(1-4):359-364.

Mahesh, I.B. and Satish, S. ( 2008 ) : Antimicrobial Activity of Some Important Medicinal Plant Against Plant and Human Pathogens .World Journal of Agricultural Sciences, 4: 839-843.

Marohasy, J. (1995): Prospects for the biological control of prickly acacia, Acacia nilotica (L.) Willd. ex Del. (Mimosaceae). PIProt Quart, 10: 24-31.

Meena, P.D.; Kaushik, P.; Shukla, S.; Soni, A.K.; Kumar, M. and Kumar, A.(2006): Anticancer and antimutagenic properties of Acacia nilotica (Linn.) on 7,12dimethylbenz(a)anthracene-induced skin papillomagenesis in Swiss albino mice. Asian Pac. J. Cancer Prev.: 7(4):627-632.

Mishra, D. and Flora, S.J.S. (2008): Differential oxidative stress and DNA damage in rat brain regions and blood following chronic arsenic exposure. Toxicology and Industrial Health, 24(4): 247-256.

Mohanty, R.B.; Padhy, S.N. and Dash, S.K. (1996): Traditional phytotherapy for diarrhoea diseases in Ganjan and Phulbani district of South Orrisa, India. Ethnobotany, 8: 60-65.

Palombo, E.A. and Semple, S.J. (2001): Antibacterial activity of traditional medicinal plants. J. Ethnopharmacol., 77: 151-157.

Perandones, C. E.; Illera, V.A.; Peckham, D.; Stunz, L.L. and Ashman, R.F. (1993): Regulation of apoptosis in vitro in mature murine spleen T-cells. J. Immunology, 151: 3521- 3529.
Samy, R.P. and Ignacimuthu, S. (2000): Antibacterial activity of some folklore medicinal plants used by tribals in Western Ghats in India. J. Ethnopharmacol., 69: 63-71.

SAS Institute (1982): SAS User's Guide: Statistics. SAS Institute Inc.,Cary, NC.

Simeonova, P. and Luster, M. (2000): Mechanisms of arsenic carcinogenicity: Genetic or epigenetic mechanisms? J. Environmental Pathology, Toxicology and Oncology, 19(3):281-286.

Singh, N.; Kumar, D.; Raisuddin, S. and Sahu, A. P. (2008): Genotoxic effects of arsenic: Prevention by functional food-jaggery. Cancer Letters, 268: 325-330.

Sotohy, S.A.; Sayed, A.N. and Ahmed, M.M. (1997): Effect of tannin-rich plant (Acacia nilotica) on some nutritional and bacteriological parameters in goats. Dtsch Tierarztl Wochenschr, 104: 432-435.

Stepanovic, S.; Antic, N.; Dakic, I. and Svabicvlahovic, M. (2003): In vitro antimicrobial activity of propilis and antimicrobial drugs. Microbiol. Res., 158: 353- 357.

Tona, L.; Kambu, K.; Ngimbi, N.; Cimanga, K. and Vlietinck, A.J. (1998):

Antiamoebic and phytochemical screening of some congolese medicinal plants. J.Ethnopharmacol., 61: 57-65.

Waclavicek, M.; Berer, A.; Oehler, L.; Stockl, J.; Schloegl, E.; Majdic,O. and Knapp, W. (2001): Calcium ionophore: a single reagent for the differentiation of primary human acute myelogenous leukaemia cells towards dendritic cells. Br J Haematol, 114 (2): 466-473.

Waller, R.A. and Duncan, D.B.( 1969): A Bayes rule for the symmetric multiple 547 comparison problems. J. Am. Stat. Assoc., 64: 1484-1503.

Wyrobek, A. J. and Bruce, W. R. (1975): Chemical induction of sperm abnormalities in mice. Proc. Natl. Acad. Sci. (USA), 72: 44254429.

Yosida,T.M. and Amano, K. (1965): Autosomal polymorphism in laboratory breed and wild norway rats. Rattus norveicus found in Misima. Chromosoma, 16: 658 - 667. 


\title{
تأثيرخلاصة نبات آكاسيا على السمية الوراثية الناتجة عن الزرنيخ
}

\author{
*إيناس صلاح الدين غالى - زينب عيد مدبولى حنفى \\ *المركز القومى للبحوث ـ معمل بيولوجيا الخلية ـ كلية العلوم (بنات ) جامعة الأزهر
}

يعتبر الزرنيخ من الملوثات البيئية النى تخترق جسم الإنسان من خلال ل الطعام والماء و الهو اء بصورة غير

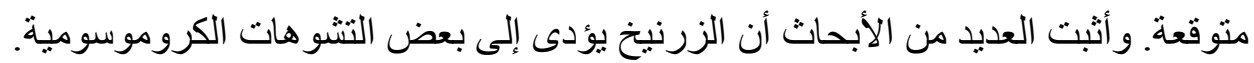

أجرى هذا البحث لدارسة التأثير الواقى لنبات الآكاسيا لتفادى الأثار الضارة على الكروموسومات

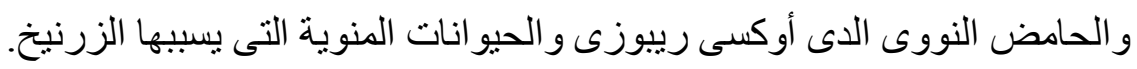
ولقد أجرى هذا البحث على الفئر ان البيضـاء الذكور والإناث والتى قسمت إلى المجموعات التالية:

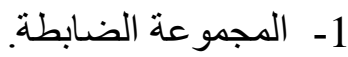

2- المجموعة المعاملة بالزرنيخ (بجر عة 5 ملى /كجم).

3- المجموعة المعاملة بنبات الأكاسيا (بجرعة 30 ملى /كجم).

4- المجموعة المعاملة بنبات الآكاسيا(بجرعة 30 ملى /كجم) و الزرنيخ (بجر عة 5 ملى /كجم).

وبعد ستة أسابيع تم تثريح عشرة من الفئران فى كل مجموعة (الذكور و الإناث) وجمعت العينات من أنسجة الكبد وذلك لتقدير تقتت الحامض النووى الدى أوكسى ريبوزى و الخصية لتحضير الحيو الناتيات

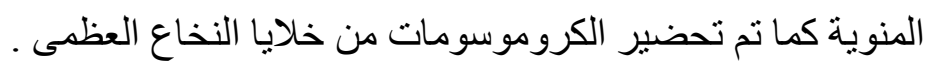

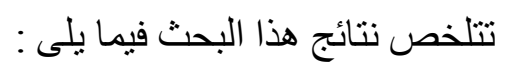

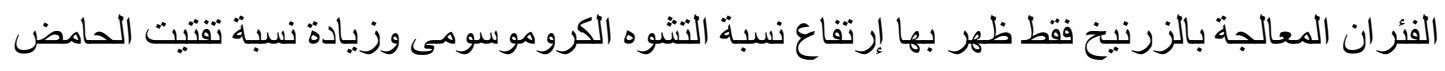

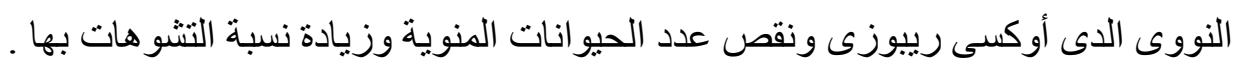

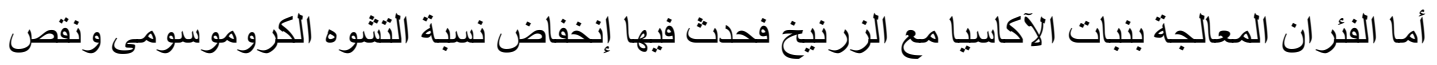

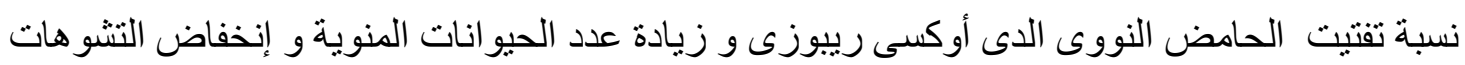

وقد أثبتت التجربة مدى فائدة نبات الآكاسيا فى حماية الخلية من الأثار الضارة للزرنيخ. 